\title{
Effects of fluoride release and solubility of resin modified glass ionomer with surface coating agents
}

\author{
Taewan Yoon, Seunghoon Yoo* \\ Department of Pediatric Dentistry, School of Dentistry, Dankook University, Cheonan, Republic of Korea
}

\begin{abstract}
Purpose: This study aimed to investigate the correlation between the solubility and the amount of fluoride release when a resin surface coating agent is applied to RMGIC. Materials and Methods: To measure the fluoride release and solubility, Fuji II LC ${ }^{\otimes}$ and Filtek ${ }^{\mathrm{TM}}$ Z350XT without a surface coating, Fuji II LC ${ }^{\circledR}$ with $\mathrm{G}$ coat plus ${ }^{\mathrm{TM}}$ and Fuji II LC ${ }^{\otimes}$ with Permaseal ${ }^{\circledR}$ were prepared. And the amount of fluoride release and solubility were measured. Results: There was no significant difference in the daily fluoride release between the surface coating agents. The cumulative fluoride release was significantly different between the groups using RMGIC at 56 days $(P<$ $0.05)$. In the solubility measurement, RMGIC without surface coating was significantly different only on the 7th day compared to the other three groups $(P<0.05)$. Conclusion: Surface coating agents can prevent the degradation of properties by the initial solvent in RMGIC. Therefore, fluoride is preserved inside the restorative material and the effect of surface coating after the addition is reduced, so that the effect on fluoride release and storage is also reduced. (J Dent Rehabil Appl Sci 2019;35(2):81-9)
\end{abstract}

Key words: surface coating agent; resin modified glass ionomer; fluoride release; solubility

\begin{abstract}
서론
치아의 우식 병소를 제거한 뒤 수복하기 위해서 다양 한 재료들과 기술이 개발되어 왔다. ${ }^{1}$ 치과에서 불소는 다 양한 방법으로 치아 우식 발생 감소를 위해 사용되고, 그 중 하나가 수복 재료를 통해 직접적으로 우식에 취약한 표면에 불소를 전달하는 방법이다. ${ }^{2}$ 전통적인 글라스아 이오노머는 장기적인 불소 유리 능력과 별다른 전 처치 없이 법랑질과 상아질에 화학적인 결합을 할 수 있어 소 아에서 와동 수복을 위해 많이 사용되고 있다. ${ }^{3}$ 그러나 이러한 전통적인 글라스아이오노머의 장점에도 불구하 고 기계적 물성이 부족과 경화 과정 중 초기 수분에 민감 하다는 임상적인 단점이 존재하였고 이러한 단점을 개 선하기 위해 레진 강화형 글라스아이오노머가 개발되었

*Correspondence to: Seunghoon Yoo

Associate professor, Department of Pediatric Dentistry, School of Dentistry,

Dankook University, 119 Dandae-ro, Dongnam-gu, Cheonan, 31116, Republic of Korea

Tel: +82-41-550-0222, Fax: +82-41-550-0118, E-mail: yoo.seunghoon@gmail.com Received: March 11, 2019/Last Revision: April 16, 2019/Accepted: May 27, 2019
\end{abstract}

다. ${ }^{4}$ 레진 강화형 글라스아이오노머의 표면에서 구강으 로 유리되는 불소는 인접한 치아의 항우식효과를 일으 키고 타액 내의 불소 농도를 높여 우식 예방에 도움을 주 며, 레진 강화형 글라스아이오노머와 접착한 치질에도 불소가 유리되며 이때 유리된 불소는 상아질에 작용하 여 광화를 증진하며 제거되지 않은 우식 병소의 재광화 를 일으킨다. ${ }^{5,6}$ 플루오로알루미노실리케이트 글라스, 광 개시제, 폴리 아크릴산, 2-hydroxyethyl methacrylate와 같은 수용성 메타크릴레이트 단량체의 혼합으로 만들어 지는 레진 강화형 글라스아이오노머는 전통적인 글라스 아이오노머의 단점인 물성을 보완하였으나 산염기 반응 으로 경화되므로 수화 및 탈수에 영향을 받는다. ${ }^{7}$ 따라서 초기 경화 과정에서 수분에 의한 영향을 보완하기 위해 표면 코팅제를 도포한다면 경화 과정 중의 수분 균형을

Copyright@ 2019 The Korean Academy of Stomatognathic Function and Occlusion. (c) It is identical to Creative Commons Non-Commercial License. 
유지하여 물성을 보존할 수 있다. ${ }^{8}$ 표면 코팅제의 종류에 바셀린, 코코아 버터, 불소 바니쉬와 레진 표면 코팅제 등 이 있다. ${ }^{9}$ 이들 중 불소 바니쉬는 치아의 표면에 있는 코 팅제의 표면에서 불소를 방출하여 치아 표면의 산에 대 한 저항성을 증진시키며 레진 표면 코팅제는 치아 표면 의 착색을 줄여주는 부가적인 장점이 있다. ${ }^{10}$ 그러나 레진 강화형 글라스아이오노머에 대한 표면 코팅제 적용은 레 진 강화형 글라스아이오노머의 불소 방출 능력에 영향을 준다. ${ }^{911,12}$ 따라서 이 연구의 목적은 레진 강화형 글라스 아이오노머에 레진 표면 코팅제를 적용하였을 때 시간이 흐름에 따라 발생하는 표면 코팅제의 영향을 용해도와 불소 유리량에 관하여 알아보는 것이다.

\section{연구 재료 및 방법}

수복 재료로는 레진 강화형 글라스아이오노머인 Fuji II LC ${ }^{\circledR}$ (GC Co. Tokyo, Japan)와 측정 과정의 오류를 확 인하기 위해 컴퍼짓 레진인 Filtek ${ }^{\mathrm{TM}}$ Z350XT (3M ESPE, St. Paul, USA)을 사용하였고, 표면 코팅제로 나노 필러 가 첨가된 레진인 G coat plus ${ }^{\mathrm{TM}}$ (GC Co.)와 필러가 들어 있지 않은 레진인 Permaseal ${ }^{\circledR}$ (Ultradent, South jordan, USA)을 사용하였다(Table 1).

불소 유리량 측정을 위해 대조군으로 표면 코팅제를 도포하지 않은 레진 강화형 글라스아이오노머 Fuji II
$\mathrm{LC}^{\circledR}$ 를 I군, Filtek ${ }^{\mathrm{TM}} \mathrm{Z} 350 \mathrm{XT}$ 를 IV군으로 설정하였고, 실험군으로 G coat plus ${ }^{\mathrm{TM}}$ 를 도포한 Fuji II LC ${ }^{\circledR}$ 를 II군, Permaseal $^{\circledR}$ 를 도포한 Fuji II LC ${ }^{\circledR}$ 를 III군으로 설정하였 다.

용해도 측정을 위해 대조군으로 표면 코팅제를 도포하 지 않은 레진 강화형 글라스아이오노머 Fuji II LC ${ }^{\circledR}$ 를 V 군, Filtek ${ }^{\mathrm{TM}}$ Z350XT를 VIII군으로 설정하였고, 실험군 으로 G coat plus ${ }^{\mathrm{TM}}$ 를 도포한 Fuji II LC ${ }^{\circledR}$ 를 VI군, Permaseal ${ }^{\circledR}$ 를 도포한 Fuji II LC ${ }^{\circledR}$ 를 VII군으로 설정하였다.

스테인리스 스틸 주형을 사용하여 직경 $10.0 \mathrm{~mm}$, 높이 $2.0 \mathrm{~mm}$ 의 시편을 제작하였다. 유리판 위에 주형을 놓고 Fuji II LC ${ }^{\circledR}$, Filtek ${ }^{\mathrm{TM}}$ Z350XT를 각각 충전한 후, Mylar strip을 덮고 가벼운 압력을 주어 나오는 잉여 재료를 제거하였다. Elipar ${ }^{\mathrm{TM}}$ Freelight 2 LED (3M ESPE, St. Paul, USA)를 사용하여 상하 양면에 각각 20 초씩 광중 합을 시행하였다. Fuji II LC ${ }^{\circledR}$ 60개, Filtek ${ }^{\mathrm{TM}}$ Z350XT 20 개의 시편이 제작되었다. 불소 유리량 측정을 위해 Fuji II LC ${ }^{\circledR}$ 를 I, II, III군으로 10 개씩 나누었고 II군에는 G coat plus ${ }^{\mathrm{TM}}$ 를 제조사의 지시에 따라 슈퍼파인 다이아몬 드 버를 이용하여 표면을 연마하고 건조한 뒤 적용하고 20 초간 광중합하였고, III군에는 Permaseal ${ }^{\circledR}$ 을 제조사의 지시에 따라 표면을 $35 \%$ 인산을 20 초간 적용 후 수세하 고 건조한 뒤 도포하고 20초간 광중합하였다. 그리고 IV 군으로 10 개의 Filtek ${ }^{\mathrm{TM}} \mathrm{Z} 350 \mathrm{XT}$ 을 사용했다. 용해도 측

Table 1. Material used

\begin{tabular}{|c|c|c|c|}
\hline Materials & Classification & Composition & Manufacturer \\
\hline Fuji II LC ${ }^{\circledR}$ & $\begin{array}{l}\text { Resin modified } \\
\text { glass ionomer }\end{array}$ & $\begin{array}{c}\text { Polyacriylic acid } \\
\text { Distilled water } \\
\text { Initiator } \\
\text { Aluminosilicate glass } \\
\text { HEMA } \\
\text { UDMA }\end{array}$ & $\begin{array}{l}\text { GC Corporation } \\
\text { (Tokyo, Japan) }\end{array}$ \\
\hline Filtek $^{\mathrm{TM}}$ Z350XT & Composite resin & $\begin{array}{c}\text { Bis-GMA } \\
\text { UDMA } \\
\text { Bis-EMA } \\
\text { Zirconia-silica filler }\end{array}$ & 3M (St. Paul, USA) \\
\hline G coat plus ${ }^{\mathrm{TM}}$ & Nanofilled coating & $\begin{array}{l}\text { Urethane methacrylate } \\
\text { Methylmethacrylate } \\
\text { Camphorquinone } \\
\text { Silicon dioxide } \\
\text { Phosphoric ester monomer }\end{array}$ & $\begin{array}{l}\text { GC Corporation } \\
\text { ('Tokyo, Japan) }\end{array}$ \\
\hline Permaseal $^{\circledR}$ & Unfilled coating & $\begin{array}{l}\text { Bis-GMA } \\
\text { Triethylene glycol dimethacrylate } \\
\text { 2-dimethylaminoethyl methacrylate }\end{array}$ & $\begin{array}{c}\text { Ultradent } \\
\text { (South jordan, USA) }\end{array}$ \\
\hline
\end{tabular}

HEMA: 2-hydroxyethyl methacrylate, UDMA: urethane dimethacrylate, Bis-GMA: bisphenol A glycidylmethacrylate, Bis-EMA: ethoxylated bisphenol A dimethacrylate. 
정을 위하여 Fuji II LC ${ }^{\circledR}$ 를 V, VI, VII군으로 10개씩 나 누었고 VI군에는 G coat plus ${ }^{\mathrm{TM}}$, VII군에는 Permaseal ${ }^{\mathbb{R}}$ 을 적용하였다. 그리고 VIII군으로 10 개의 Filtek ${ }^{\mathrm{TM}}$ Z350XT을 사용했다(Table 2).

각 군 당 10 개의 시편을 $3 \mathrm{~mL}$ 탈이온수로 채워진 폴리 에틸렌 튜브에 넣고 밀봉 뒤 $37 \pm 1^{\circ} \mathrm{C}$ 의 항온기에 보관 하였다. 불소 유리량은 시편 제작 후 단기적, 장기적 불소 유리에 대한 표면 코팅제의 영향을 알아보기 위하여 1일, 3 일, 7 일, 14 일, 21 일, 28 일, 56일에 측정하였다. 측정 시 마다 $3 \mathrm{~mL}$ 의 새로운 탈이온수로 교환하였다. 불소 유리 량 측정은 매 측정 시 시편 용액과 같은 온도의 $0.1 \mathrm{ppm}$, $1 \mathrm{ppm}, 10 \mathrm{ppm}$ 의 불소 표준 용액(Fluoride standard solution, Istek, Korea)을 사용하여 농도 보정 후 시행 하였으며, 시편을 꺼낸 폴리에틸렌 튜브에 동일한 양의 TISAB II (Total Ionic Strength Adjusting Buffer, Istek, Korea)용액을 적용한 후 $\mathrm{pH} / \mathrm{ISE}$ meter (750P, Istek, Korea)에 불소전극(Fluoride combination electrode, Istek, Korea)을 연결하여 각 용액 내에 유리된 불소 유리 량을 측정하였다. ${ }^{13,14}$

각 10 개의 시편으로 이루어진 4 개의 군에서 용해도를 측정하였다. 두 대의 건조기를 사용하여 $37 \pm 1{ }^{\circ} \mathrm{C}$ 에서 22 시간, $23 \pm 1^{\circ} \mathrm{C}$ 에서 2 시간 보관한 후 $\pm 0.1 \mathrm{mg}$ 의 정 확도로 전자저울(Explorer, OHAUS, USA)을 사용하여 무게를 측정하여 용해 전 무게를 $\mathrm{M}_{1}$ 으로 기록하였다. 시 편은 $10 \mathrm{~mL}$ 의 탈이온수가 담긴 폴리에틸렌 튜브에 밀봉 후 $37 \pm 1^{\circ} \mathrm{C}$ 의 항온기에서 보관하였으며 7일, 14 일, 21 일, 28 일, 56 일에 동일한 방법으로 무게를 측정하였고 이 값을 $\mathrm{M}_{2}$ 로 기록하였다. 또한 직경 $10.0 \mathrm{~mm}$ 높이 $2.0 \mathrm{~mm}$ 의 시편 부피를 산출하여 $\mathrm{V}$ 로 기록한 후 다음과 같은 공 식으로 용해도를 산출하였다.

$$
W_{\text {sol }}=\frac{M_{1}-M_{2}}{V}
$$

$\mathrm{W}_{\mathrm{sol}}$ : 시험 재료의 용해도 $\left(\mathrm{mg} / \mathrm{mm}^{3}\right)$

$\mathrm{V}$ : 시편의 부피 $\left(\mathrm{mm}^{3}\right)$

$\mathrm{M}_{1}, \mathrm{M}_{2}$ : 시편의 무게 $(\mathrm{mg})$

불소 유리량, 용해도의 수치를 SPSS 21.0 (SPSS Inc, Chicago, USA) 프로그램을 사용하여 통계 분석하였다. 각 군 간의 불소 누적 유리량, 56일간의 용해도를 Kruskal-Wallis test로 유의성을 검정하고 Scheffe test로 사후 검정하였다.

\section{결과}

I군(Uncoated Fuji II LC ${ }^{\circledR}, 7.90 \pm 0.81$ ppm), II군(Fuji II LC $^{\circledR}$ with $G$ coat plus ${ }^{\text {TM }}, 3.63 \pm 0.38$ ppm), III군(Fuji II LC ${ }^{\circledR}$ with Permaseal ${ }^{\circledR}, 4.20 \pm 0.47 \mathrm{ppm}$ )에서 1일째에 가장 높은 불소 일간 유리량을 보였으며 56일까지 감소 하는 양상을 보였다. I군은 II군과 III군에 비하여 56일간 높은 불소 일간 유리량을 보였다. I군과 II군, I군과 III군 은 실험 시작 1일 후부터 56일 까지 불소 일간 유리량이 유의한 차이를 보였으나 $(P<0.05) \mathrm{II}$ 군과 III군은 모든 측정 기간 동안 유의한 차이를 나타내지 않았다(Fig. 1). $\mathrm{I}$ 군 $(68.81 \pm 1.74 \mathrm{ppm})$ 은 다른 세 군에 비하여 56일까지 높은 불소 누적 유리량을 보였으며 III군(19.72 \pm 1.01 ppm), II군(16.67 $\pm 0.97 \mathrm{ppm}), \mathrm{IV}$ 군(0.27 $\pm 0.10 \mathrm{ppm})$ 순서로 불소 누적 유리량을 나타내었다(Table 3, Fig. 2). 56 일 째의 불소 누적 유리량은 I군과 II군, I군과 III군은 각각 유의한 차이를 보였으나 $(P<0.05) \mathrm{II}$ 군과 $\mathrm{III}$ 군 간 의 유의한 차이는 없었다.

Table 2. Sample grouping

\begin{tabular}{|c|c|c|c|c|}
\hline Test & Material & Group & Surface coating agent & Number \\
\hline \multirow[t]{4}{*}{ Fluoride release } & Fuji II LC ${ }^{\circledR}$ & $\mathrm{I}$ & Non coated & 10 \\
\hline & & II & G coat plus ${ }^{\text {TM }}$ & 10 \\
\hline & & III & Permaseal $^{\circledR}$ & 10 \\
\hline & Filtek $^{\mathrm{TM}}$ Z350XT & IV & Non coated & 10 \\
\hline \multirow[t]{4}{*}{ Solubility } & Fuji II LC ${ }^{\circledR}$ & $\mathrm{V}$ & Non coated & 10 \\
\hline & & VI & G coat plus ${ }^{\mathrm{TM}}$ & 10 \\
\hline & & VII & Permaseal $^{\circledR}$ & 10 \\
\hline & Filtek $^{\mathrm{TM}}$ Z350XT & VIII & Non coated & 10 \\
\hline
\end{tabular}




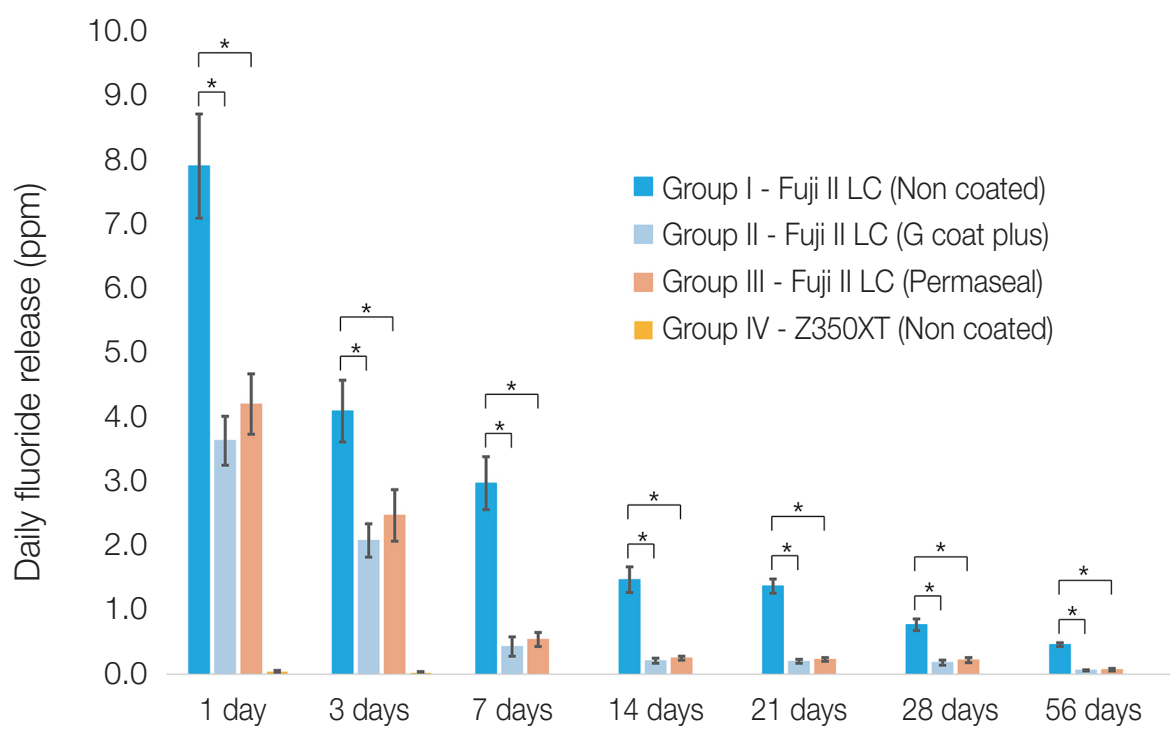

Fig. 1. Daily fluoride release for 56 days. Kruskal-wallis test and Scheffe post hoc test $(*: P<0.05)$.

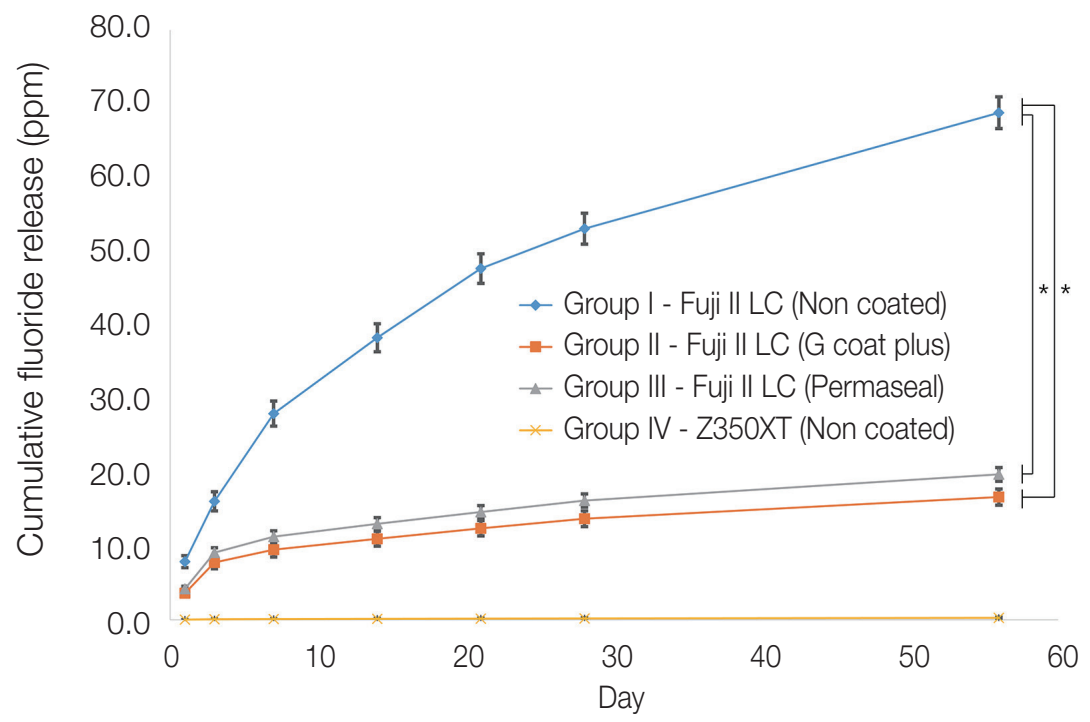

Fig. 2. Cumulative fluoride release for 56 days. Kruskal-wallis test and Scheffe post hoc test $(*: P<0.05)$.

Table 3. Cumulative fluoride release of each group for 56 days

\begin{tabular}{|c|c|c|c|}
\hline & & & Cumulative fluoride release ( $\mathrm{ppm})$ \\
\hline Group I & Fuji II LC ${ }^{\circledR}$ & Non coated & $68.81 \pm 1.74^{a}$ \\
\hline Group II & Fuji II LC ${ }^{\circledR}$ & G coat plus ${ }^{\mathrm{TM}}$ & $16.67 \pm 0.97^{\mathrm{b}}$ \\
\hline Group III & Fuji II LC ${ }^{\circledR}$ & Permaseal $^{\mathbb{R}}$ & $19.72 \pm 1.01^{\mathrm{b}}$ \\
\hline Group IV & Filtek $^{\mathrm{TM}} \mathrm{Z} 350 \mathrm{XT}$ & Non coated & $0.27 \pm 0.1$ \\
\hline
\end{tabular}

Kruskal-Wallis Test.

a, b: The same character means no statistical difference (Mean \pm Standard deviation). 
0.06

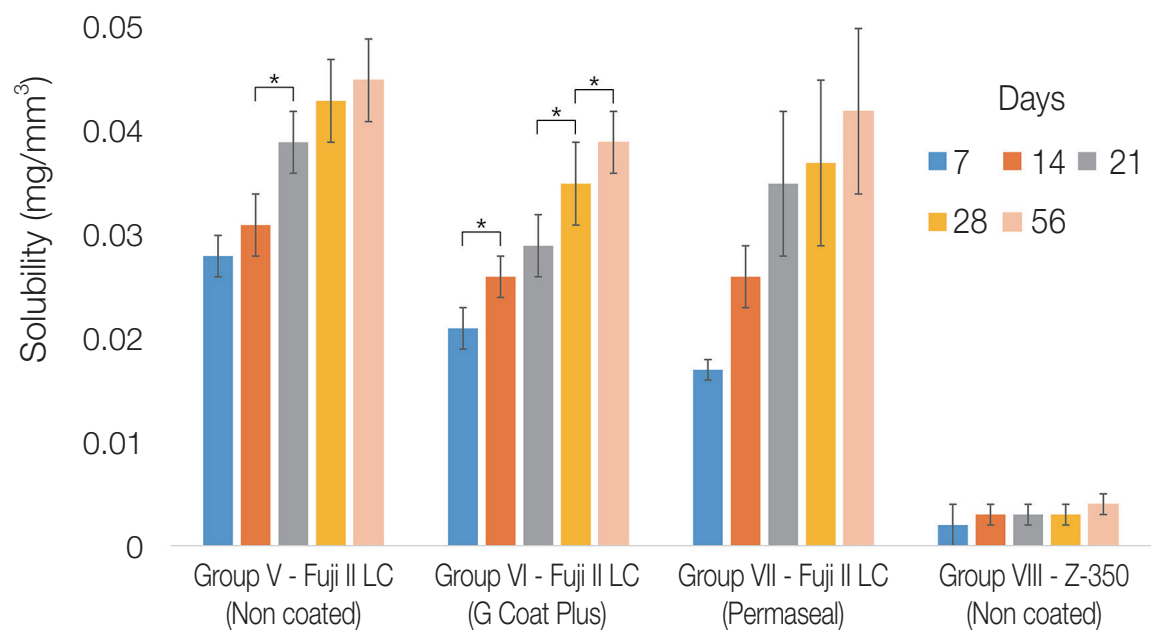

Fig. 3. Solubility of experimental materials for 56 days. Kruskal-wallis test and Scheffe post hoc test $(*: P<0.05)$.

V (Uncoated Fuji II LC ${ }^{\circledR}$ ), VI (Fuji II LC ${ }^{\circledR}$ with G coat plus $^{\text {TM }}$ ), VII (Fuji II LC ${ }^{\circledR}$ with Permaseal ${ }^{\circledR}$ ), VIII (Uncoated Filtek ${ }^{\mathrm{TM}}$ Z350XT)군에서 56일간 재료의 용해 가 확인되었다. 56 일째의 용해도 측정에서 $\mathrm{V}$ 군 $(0.045 \pm$ $\left.0.004 \mathrm{mg} / \mathrm{mm}^{3}\right)$ 에서 가장 큰 용해도를 나타내었고 VIII 군 $\left(0.004 \pm 0.001 \mathrm{mg} / \mathrm{mm}^{3}\right)$ 에서 가장 낮은 용해도를 나 타내었다(Fig. 3). V군은 다른 세 군에 비하여 용해도 측 정 기간 동안 높은 용해도를 보였으나 7일째의 측정에서 만 네 군간의 유의한 차이가 있었다 $(P<0.05)$.

\section{고찰}

전통적인 글라스아이오노머는 산염기 경화 반응만으 로 경화하지만 레진 강화형 글라스아이오노머의 경화는 주로 산염기 경화 반응에 의해 일어나며 보조적으로 광 중합에 의해 경화된다. ${ }^{15}$ 레진 강화형 글라스아이오노머 의 광중합 반응은 초기 수분에 의한 영향과 전통적인 글 라스아이오노머의 초기 경화 단계에서의 산염기 반응 중 의 탈수의 영향을 감소시킨다. ${ }^{16}$ 그러나 광중합을 위해 첨가되는 친수성 레진인 HEMA는 높은 수분 흡수 능력 을 가지며 이는 레진 강화형 글라스아이오노머가 경화 과정 중 수분의 영향을 받게 만든다. ${ }^{17}$ 특히 레진 강화형 글라스아이오노머는 물이나 생리식염수에 보관되었을
때 수분을 더욱 많이 흡수한다. ${ }^{8}$ 수분의 영향은 레진 강 화형 글라스아이오노머의 수복 재료로서의 물성을 손상 시킨다. ${ }^{18}$ 레진 강화형 글라스아이오노머에 표면 코팅제 를 적용한다면 경화 과정 중 수분에 의한 초기 물성 저하 를 줄일 수 있다. ${ }^{19}$

그러나 표면 코팅제를 적용함으로 불소 유리량에 있어 서는 단점으로 작용할 수 있다. 레진 강화형 글라스아이 오노머에서의 불소 유리량은 기질 구조 성분, 필러, 불소 를 방출하는 요소에 영향을 받는다. ${ }^{20}$ 또한 보관 환경, 보 관 용액 교환 횟수 및 빈도, 타액의 구성 및 $\mathrm{pH}$, 치태 형 성 유무, 분말과 용액 비율, 혼합 방법 및 중합 시간, 노출 된 표면과 같은 요소에도 영향을 받는다. 이와 같은 요소 들 중 레진 강화형 글라스아이오노머의 불소 유리량은 사용된 시편의 크기보다는 시편이 노출된 표면에 더욱 영 향을 받는다. ${ }^{21}$ 따라서 시편에 대한 레진 표면 코팅제의 적용은 노출 표면을 감소시킨다.

이번 연구에서는 G Coat Plus ${ }^{\mathrm{TM}}$ 와 Permaseal ${ }^{\circledR}$ 을 사용 하였다. 나노 필러가 포함된 레진 표면 코팅제인 G Coat $\mathrm{Plus}^{\mathrm{TM}}$ 는 매우 낮은 점도와 높은 친수성의 특징을 가지 며 레진 강화형 글라스아이오노머에 자가 접착하여 표 면을 밀봉한다. ${ }^{22}$ Permaseal $^{\circledR}$ 은 표면 침투 실란트로 낮은 점도와 높은 흐름성을 가진 필러가 들어있지 않은 레진 으로 모세관 현상을 사용하여 변연의 틈을 봉쇄한다. ${ }^{23}$ 
이번에 진행한 불소 유리량 연구에서 사용된 모든 레 진 강화형 글라스아이오노머에서 56일까지 불소가 방출 되었다. 레진 강화형 글라스아이오노머를 사용한 모든 군은 측정 후 1 일에서 가장 높은 불소 유리량을 보였으 며 그 이후 유리량은 줄어들었으나 56일까지 방출되었 다. 컴포짓 레진은 불소 유리량이 없고 용해도가 변동이 적어 실험 중 발생할 수 있는 측정 오류를 확인하기 위해 사용되었고, 컴포짓 레진에서도 불소 유리가 확인되었으 나 이는 컴포짓 레진에서 불소가 유리 되었기 보다는 측 정 기기의 한계로 인한 연구 과정 중의 오류로 판단된다. 이 연구에서 측정된 결과는 글라스아이오노머의 불소 방 출량은 연구 설계에 따라 다양하지만 혼합 후 초기 24시 간에서 48 시간 사이에 가장 높은 불소 방출량을 보이고 그 이후에는 감소하지만 지속적으로 오랫동안 방출하 는 양상을 보인다는 다른 연구 결과들과 유사한 양상을 보였다. ${ }^{24,25}$ 초기의 높은 불소 방출의 이유는 수복 재료 가 용액에 노출되었을 때 재료의 표면이 용해되어 불소 가 급격히 유리되는 현상 때문이다. 이번 결과에서도 레 진 표면 코팅제를 적용한 군과 그렇지 않은 군의 불소 유 리량 양상은 달랐으며 레진 강화형 글라스아이오노머에 레진 표면 코팅제를 적용하였을 때 적은 양의 불소 유리 량이 방출된다는 다른 연구 결과들과 유사한 양상을 보 였다. ${ }^{11,12}$ 레진 표면 코팅제를 적용하지 않은 군에서 3 일 째까지 많은 불소 유리량을 나타내었으나 그 이후에 점 진적으로 감소하는 양상을 보였으며 이는 다른 연구 결 과들의 불소 유리 양상과 유사하였다. ${ }^{26}$ 레진 표면 코팅 제를 적용한 군에서는 7 일 까지는 불소 유리량의 꾸준 한 감소를 보였으나 14 일 이후에는 불소 유리량이 완만 한 감소량을 보였으며 이는 다른 연구 결과에서 보인 양 상과 유사하였다. ${ }^{27}$ 이러한 결과로 미루어 보아 레진 강 화형 글라스아이오노머에 레진 표면 코팅제를 적용하는 것은 레진 강화형 글라스아이어노머의 불소 유리를 완전 히 방해하지 않으며 지속적으로 불소가 유리된다는 것을 알 수 있다. 레진 표면 코팅제의 종류에 따른 레진 강화형 글라스아이오노머의 불소 유리량 차이는 실험 기간 동 안 $\mathrm{G}$ coat plus ${ }^{\mathrm{TM}}$ 를 적용한 레진 강화형 글라스아이오노 머에서 유리된 불소가 Permaseal ${ }^{\circledR}$ 을 적용한 레진 강화형 글라스아이오노머보다 적은 양이 방출되었으나 유의한 차이는 없었다.

이번에 진행한 용해도 연구에서는 레진 표면 코팅제를 적용하지 않은 레진 강화형 글라스아이오노머가 적용한 레진 강화형 글라스아이오노머보다 단기적으로 높은 용
해도를 보였는데, 이로써 처음 7일간 발생하는 레진 강화 형 글라스아이오노머가 용액에 노출되었을 때 재료의 표 면이 용해되어 불소가 급격히 유리되는 현상을 레진 표 면 코팅제가 감소시킴을 알 수 있다. 그리고 56일 후까지 레진 표면 코팅제를 적용하지 않은 레진 강화형 글라스 아이오노머가 표면 코팅제를 적용한 레진 강화형 글라스 아이오노머보다 높은 용해도를 나타내었다. 7 일째의 용 해도 차이는 표면 코팅제 종류에 따라 유의한 차이가 존 재하였으나 그 이후의 용해도 변화는 유의한 차이는 없 었다. 불소 유리량과 용해도를 전체적인 연구 기간으로 보았을 때, 모든 레진 강화형 글라스아이오노머를 사용 한 군에서 7일 이후로는 유의한 차이가 없는 용해도 변화 를 보였고 그에 대응하는 기간의 불소 유리량은 표면 코 팅제를 적용 시 지속적이나 적은 양의 불소가 유리되었 고 이는 표면 코팅제를 도포하지 않았을 때와 비교하여 유의한 차이를 보였으나 표면 코팅제 간의 유의한 차이 는 없어 초기 7일 이후의 불소 유리량과 용해도의 상관관 계를 알기에는 유의한 차이가 부족하다. 전통적인 글라 스아이오노머와 레진 강화형 글라스아이오노머는 장기 적으로 스트론튬, 나트륨, 규소와 같은 주요 성분들을 방 출하기 때문에 장기적인 용해도는 주요 성분들의 변화와 연관되어 있을 것이다. ${ }^{28}$ 또한 레진 강화형 글라스아이오 노머는 불소의 흡수가 가능하다는 특징을 가진다. ${ }^{29}$ 레진 표면 코팅제를 적용한 것이 레진 강화형 글라스아이오노 머의 불소 유리를 감소시키나 완전히 막지 않는 것으로 보아 구강 내 환경에서 일어나는 타액 내 성분의 흡수도 발생할 것으로 유추할 수 있다. 이 연구는 탈이온수에 레 진 강화형 글라스아이오노머를 보관하였고 보관 용액이 다르기 때문에 재료의 용해와 같은 물성의 변화가 다르 다는 한계가 존재한다. ${ }^{30}$ 그리고 구강 내를 완전히 재현 하지 못하였다는 한계가 존재한다. 그렇지만 이 연구를 통해 표면 코팅제에 의해 레진 강화형 글라스아이오노머 의 수분에 의한 경화 초기 표면 용해로 발생하는 불소 유 리가 감소함을 확인하였고 이는 임상적으로 경화 초기에 재료가 용해되지 않아 구강 내로 구성 성분이 용출되지 않았기 때문에 레진 강화형 글라스아이오노머의 구성 요 소가 보존되어 수복재 내부에 불소가 보존되고 있다 볼 수 있으며 시간이 흐름에 따라 표면 코팅제의 효과가 감 소하는 것은 초기 경화 과정에서의 물성 유지에 유리하 며 향후 불소의 방출과 저장에 영향을 주는 것이 감소한 다고 유추할 수 있다. 


\section{결론}

연구 결과 모든 레진 강화형 글라스아이오노머군에 서 연구 첫째 날 불소 유리량이 가장 많았지만 표면 코팅 제 적용시 불소 유리량은 감소하였다. 표면 코팅제에 의 한 일간 불소 유리량 변화는 표면 코팅제 종류 간에 유의 한 차이가 없었다. 56 일 간의 누적 불소 유리량 또한 표 면 코팅제를 적용하였을 때 적은 양이 방출되었고 표면 코팅제 간의 유의한 차이는 없었다. 레진 강화형 글라스 아이오노머의 용해도는 표면 코팅제를 적용하였을 때 감 소하였으나 7일째만 재료간 유의한 차이가 있었다. 표면 코팅제는 레진 강화형 글라스아이오노머 수복재에서 초 기 용매에 의한 구성 요소의 용해를 막아 물성을 보존하 여 수복재 내부에 불소를 보존하며 추 후 효과가 감소하 여 불소의 방출과 저장에 대한 영향 또한 감소한다.

\section{ORCID}

Taewan Yoon https://orcid.org/0000-0002-9935-4081

Seunghoon Yoo https://orcid.org/0000-0003-2815-512X

\section{References}

1. Moses J, Rangeeth BN, Gurunathan D. Prevalence of dental caries, socio-economic status and treatment needs among 5 to 15 year old school going children of Chidambaram. JCDR 2011;5:146-51.

2. Krämer N, Schmidt M, Lücker S, Domann E, Frankenberger R. Glass ionomer cement inhibits secondary caries in an in vitro biofilm model. Clin Oral Ivestig 2018;22:1019-31.

3. Croll TP, Nicholson JW. Glass ionomer cement in pediatric dentistry: review of the literature. Pediatr Dent 2002;24:423-9.

4. Khoroushi M, Keshani F. A review of glass-ionomers: From conventional glass-ionomer to bioactive glass-ionomer. Dent Res J 2013;10:411-20.

5. Haznedaroğlu E, Güner Ş, Duman C, Menteş A. A 48-month randomized controlled trial of caries prevention effect of a one-time application of glass ionomer sealant versus resin sealant. Dent Mater J 2016;35:532-8.

6. Itota T, Nakabo S, Iwai Y, Konishi N, Nagamine M,
Torii Y. Inhibition of artificial secondary caries by fluoride-releasing adhesives on root dentin. J Oral Rehabil 2002;29:523-7.

7. Berzins DW, Abey S, Costache MC, Wilkie CA, Roberts HW. Resin modified glass-ionomer setting reaction competition. J Dent Res 2010;89:82-6.

8. Karaoğlanoğlu S, Akgül N, Ozdabak HN, Akgül HM. Effectiveness of surface protection for glass-ionomer, resin modified glass ionomer and polyacid-modified composite resins. Dent Mater J 2009;28:96-101.

9. Kamatham R, Reddy SJ. Surface coatings on glass ionomer restorations in Pediatric dentistry - Worthy or not? J Indian Soc Pedod Prev Dent 2013;31:22933.

10. Söderholm KJ. Coatings in dentistry - a review of some basic principles. Coatings 2012;2:138-59.

11. Hattab FN, Amin WM. Fluoride release from glass ionomer restorative materials and the effects of surface coating. Biomaterials 2001;22:1449-58.

12. Tiwari S, Nandlal B. Effect of nano-filled surface coating agent on fluoride release from conventional glass ionomer cement: an in vitro trial. J Indian Soc Pedod Prev Dent 2013;31:91-5.

13. Lee MJ, Kim KM. A study on the fluoride release, microhardness and cytotoxicity of fluoride releasing restorative materials. Korean J Dent Mater 2016;43:299-306.

14. Lee KY, Lee SH, Lee NY, Jih MK. A Comparison of the Amount of Fluoride Ion Released and Remineralization Effect on the Initial Caries Lesion of the Various Fluoride Varnishes. J Korean Acad Pediatr Dent 2016;43:443-51.

15. Nicholson JW. Glass ionomer dental cements: update. Mater Technol 2010;25:8-13.

16. Piwowarczyk A, Lauer HC. Mechanical properties of luting cements after water storage. Oper Dent 2003;28:535-42.

17. Hosaka K, Nakajima M, Takahashi M, Itoh S, Ikeda M, Tagami J, Pashley DH. Relationship between mechanical properties of one-step self-etch adhesives and water sorption. Dent Mater 2009;26:360-7.

18. Chuang SF, Jin YT, Tsai PF, Wong TY. Effect of various surface protections on the margin microleakage of resin-modified glass ionomer cements. J 
Prosthet Dent 2001;86:309-14.

19. Jevnikar P, Sersa I, Sepe A, Jarh O, Funduk N. Effect of surface coating on water migration into resin modified glass ionomer cements: a magnetic resonance micro-imaging study. Magn Reson Med 2000;44:686-91.

20. Yli-Urpo H, Vallittu PK, Närhi TO, Forsback AP, Väkiparta M. Release of silica, calcium, phosphorus, and fluoride from glass ionomer cement containing bioactive glass. J Biomater Appl 2004;19:520.

21. Hayacibara MF, Ambrozano GM, Cury JA. Simultaneous release of fluoride and aluminum from dental materials in various immersion media. Oper Dent 2004;29:16-22.

22. Gurgan S, Kutuk ZB, Ergin E, Oztas SS, Cakir FY. Four-year randomized clinical trial to evaluate the clinical performance of a glass ionomer restorative system. Oper Dent 2015;40:134-43.

23. Mousavinasab SM, Khosravi K, Tayebghasemi N. Microleakage Assessment of Class V Composite Restorations Rebonded with Three Different Methods. Dent Res J 2008;5:21-6.

24. Shiozawa M, Takahashi H, Iwasaki N. Fluoride release and mechanical properties after 1-year water storage of recent restorative glass ionomer ce- ments. Clin Oral Investig 2014;18:1053-60.

25. Karantakis P, Helvatjoglou-Antoniades M, Theodoridou-Pahini S, Papadogiannis Y. Fluoride release from three glass ionomers, a compomer, and a composite resin in water, artificial saliva, and lactic acid. Oper Dent 2000;25:20-5.

26. Yip HK, Smales RJ. Fluoride release from a polyacid-modified resin composite and 3 resinmodified glass-ionomer materials. Quintessence Int 2000;31:261-6.

27. Mazzaoui SA, Burrow MF, Tyas MJ. Fluoride release from glass ionomer cements and resin composites coated with a dentin adhesive. Dent Mater 2000;16:166-71.

28. Wiegand A, Buchalla W, Attin T. Review on fluoride-releasing restorative materials-fluoride release and uptake characteristics, antibacterial activity and influence on caries formation. Dent Mater 2007;23:343-62.

29. Gao W, Smales RJ. Fluoride release/uptake of conventional and resin-modified glass ionomers, and compomers. J Dent 2001;29:301-6.

30. Aliping-McKenzie M, Linden RW, Nicholson JW. The effect of saliva on surface hardness and water sorption of glass-ionomers and "compomers". J Mater Sci Mater Med 2003;14:869-73. 


\section{표면 코팅제의 레진 강화형 글라스아이오노머 불소 유리량 및 용해도에 대한 효과}

\section{윤태완, 유승훈*}

단국대학교 치과대학 치의학과 소아치과학교실

목적: 이 연구의 목적은 RMGIC에 레진 표면 코팅제를 적용하였을 때 용해도와 불소 유리량 간의 상관관계를 알아보는 것이다.

연구 재료 및 방법: 불소 유리량과 용해도 측정을 위해 표면 코팅제를 도포하지 않은 Fuji II LC ${ }^{\circledR}$, Filtek ${ }^{\mathrm{TM}}$ Z350XT와 G coat plus ${ }^{\mathrm{TM}}$ 를 도포한 Fuji II LC ${ }^{\mathbb{B}}$, Permaseal ${ }^{\mathbb{B}}$ 를 도포한 Fuji II LC ${ }^{\mathbb{B}}$ 를 준비하고 불소 유리량과 용해도를 측정하였다.

결과: 일간 불소 유리량은 표면 코팅제 간의 차이는 유의하지 않았다. 불소 누적 유리량은 56일에 RMGIC를 사용한 군 에서 유의한 차이를 보였다 $(P<0.05)$. 용해도 측정에서 표면 코팅제를 도포하지 않은 RMGIC가 다른 세 군에 비하여 7 일 째에서만 유의한 차이를 보였다 $(P<0.05)$.

결론: 표면 코팅제는 RMCIG에서 초기 용매에 의한 물성 저하를 막아 수복재 내부에 불소를 보존하며 추후 수복재의 불 소의 방출과 저장에 대한 영향 또한 감소한다.

(구강회복응용과학지 2019;35(2):81-9)

주요어: 표면 코팅제; 레진 강화형 글라스아이오노머; 불소 유리량; 용해도 